\title{
Molecular Identification of Pathogenic Leptospirosis with Zoonotic Potential in Urban Rats (Rattus Rattus) in Banyuwangi District
}

\author{
Maya Nurwartanti Yunita ${ }^{1 *}$, Bodhi Agustono ${ }^{2}$, Muhammad Thohawi Elziyad Purnama ${ }^{3}$ \\ ${ }^{1}$ Department of Veterinary Pathology, ${ }^{2}$ Department of Animal Husbandry, ${ }^{3}$ Department of \\ Veterinary Anatomy, Veterinary Medicine Faculty, Airlangga University, Campus C \\ Mulyorejo, Surabaya, East Java, Indonesia 60115 \\ * Corresponding author: mayanurwantanti@fkh.unair.ac.id
}

\begin{abstract}
Leptospirosis is a zoonotic disease that occurs globally. Leptospires are transmitted through the urine of infected mice, through injured skin or mucosal invasion. Infection can occur through direct contact or through contact with contaminated water or soil. This qualitative research uses a combination of epidemiological studies with a case study approach. Rat urine metabolism samples will be tested by testing the base pair chain through the Polymerase Chain Reaction method for leptospirosis. Electrophoresis results showed 5\% percent of positive samples with $330 \mathrm{bp}$. The conclusion of this study, the molecular identification of leptospirosis from rat urine using the Polymerase Chain Reaction technique are found positive results so prevention is needed to control the distribution of pathogenic leptospirosis bacteria. Urban rats (Rattus rattus) in leptospirosis transmission are considered as the most important leptospira reservoir, because high population densities of this species can cause an increase in the spread of leptospirosis.
\end{abstract}

Keywords: Banyuwangi, Leptospirosis, Urban rats, Zoonosis

\section{Introduction}

Globally, leptospirosis is estimated to cause 1.03 million cases and 58,900 deaths each year. This estimate places leptospirosis as the main cause of zoonosis. In addition, major leptospirosis morbidity and mortality are in the poorest regions of the world and in areas where surveillance is not routinely carried out (Costa et al., 2015). Most cases of leptospirosis in Southeast Asia occur in Indonesia, Thailand and Sri Lanka (Katulistiwa and Lestari, 2015). Rats are the main infectious agent of leptospirosis in Indonesia (Widoyono, 2011).

The leptospirosis mortality rate in Indonesia reaches 2.5 - 16.5 percent on the year (Mulyono et al., 2016). An increase in human disease is associated with a reservoir of small mammals, so it is important to look at what current scientific problems in rodent-borne diseases and their impact on public health (Meerburg et al., 2009). The most common source of human infection throughout the world is mice, although other animals can also be the source. Pathogenic leptospires live in the host kidney of rodents and are excreted in the urine (Gratz, 2006).

Wild animals and pets, especially rat and small animals, cows, pigs, and dogs can be carriers of leptospirosis (Adler and Pena, 2010). Leptospirosis spreads through contact, directly or indirectly, between injured mucosa or human skin and infected animals such as rats, dogs, cats, and other home animals (Shieh et al., 2006). Zoonoses in humans and animals are barriers to animal husbandry and human health. Humans are infected through skin contact or mucous membranes with the urine of infected animals or urine-contaminated water or soil (Gratz, 2006). Leptospires enter human circulation through penetration of 
abrasive skin or mucous membranes (eyes, mouth, nasopharynx, or esophagus) (Amin, 2016; Khairiyah, 2016).

The PCR test is used to detect leptospires in clinical and environmental samples that have been reported. This Polymerase Chain Reaction test is sensitive and can distinguish between pathogenic and non-pathogenic species, although further research needs to confirm this, and has important implications for patient care because the diagnosis can be made earlier (Bal et al., 1994; Wagenaar et al., 2000 ). Research on leptospirosis for the Banyuwangi region has never been done before, because of this background, we raised a study entitled a pathology study to identify molecular leptospirosis pathogens with zoonotic potential in urban rats (Rattus Rattus) in Banyuwangi.

\section{Materials and Methods}

Qualitative research by using a case study approach. Determination of place based on random sampling with all samples considered homogeneous. The research sample was taken from a dense residential and market area in Banyuwangi which will then be continued testing the sample at the veterinary microbiology laboratory of Veterinary Medicine Faculty, Airlangga University.

The materials that are used rat samples or urine, reagents and Polymerase Chain Reaction kits, and primers. The tools are used animal traps, metabolic cages, and urine sample pots. Catching mice using 60 live traps for several days Catching mice is done by setting traps starting at 16:00 local time and taken between 06.00-09.00 local time. After the sample is obtained, it is then transferred to a metabolic stable to wait for the rat urine samples to be collected.

The urine sample is then tested by Polymerase Chain Reaction method to determine the diversity of the characteristics of the base pair obtained with primary leptospirosis. Pathogenic specific primers $16 \mathrm{~S}$ rRNA Forward 5 'GAG-TCT-GGG-ATA-ACT-TT-3' and Reverse 5 'TCA-CAT-CG (CT) -TGC-TTA-TTT-T-3' with target band $330 \mathrm{bp}$. The Mix Master made was incubated at 930C for 1 minute (Initial Denaturation). Furthermore, with a cycle of 35 times the master mix was continued incubated at 930C for 1 minute for denaturation. Then the mixture was incubated at $480 \mathrm{C}$ for 1 minute for annealing, incubated at $720 \mathrm{C}$ for 10 minutes for final polymerization and continued electrophoresis.

\section{Results and Discussion}

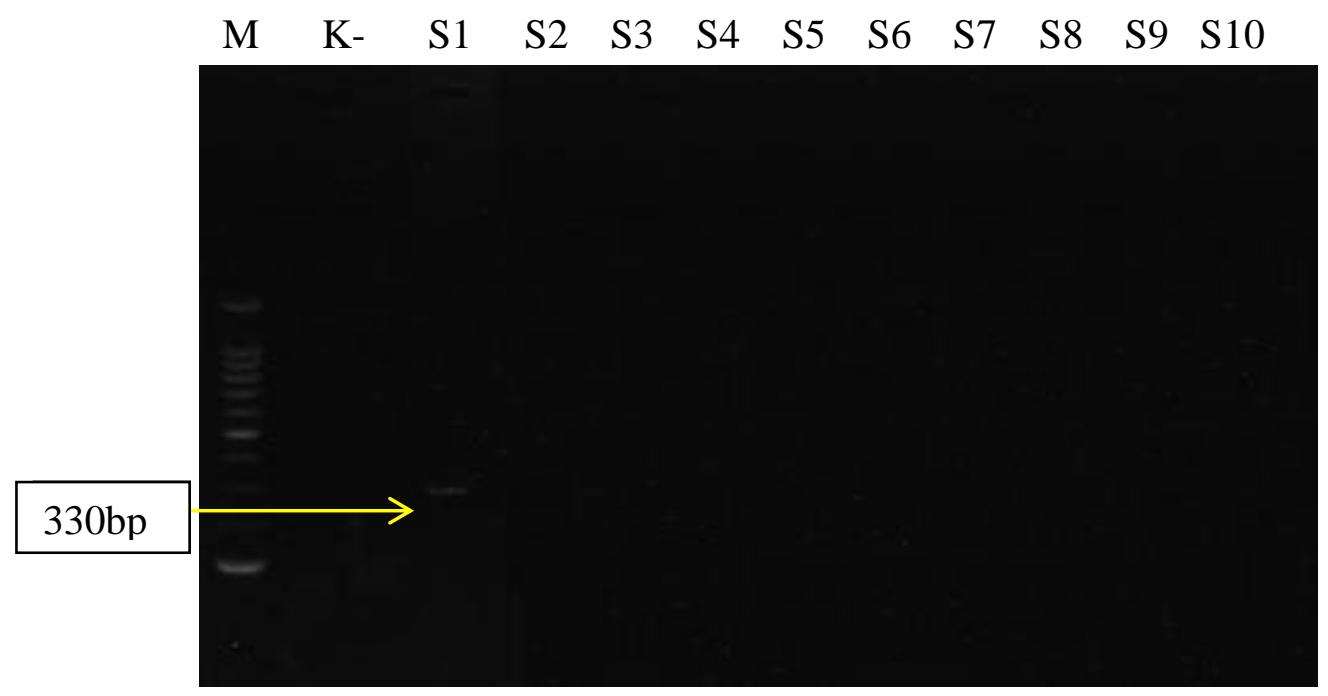


Figure 1. Polymerase Chain Reaction Electrophoresis Results of rats urine samples (M: DNA marker 100 bp, K-: Negative Control, S1: Sample 1, S2: Sample 2, S3: Sample 3, S4: Sample 4, S5: Sample 5, S6: Samples 6, S7: Sample 7, S8: Sample 8, S9: Sample 9, S10: Sample 10)

Twenty rats were caught in the Banyuwangi area. From Figure 1 it can be observed that from twenty rat urine samples captured in the Banyuwangi area there was a positive S1 sample (5\%) containing pathogenic leptospirosis through Polymerase Chain Reaction examination and produced 330 base pairs.

Banyuwangi is an area in the province of East Java, Indonesia. The climate in this area is included in the tropics where there is a dry and rainy season. Flooding has occurred several times, with the presence of identified pathogenic Leptospira bacteria as being feared to spread to humans or livestock. Several studies have reported that changes in rodent demographics, intermediate host populations and environmental factors can change the risk of transmission of zoonotic pathogens (Costa et al., 2014a). Most leptospirosis infections in cattle or humans are often related to contact with rat urine or urine soil. Many tropical urban areas experience epidemics of leptospirosis during periods of high rainfall and floods; outbreaks can occur during the winter rainy season (Sarkar et al., 2002).

Leptospira infections in humans can occur without symptoms, but diseases with different severity and clinical signs can occur, ranging from minor illnesses such as influenza to more serious illnesses such as liver dysfunction to jaundice, kidney damage, bleeding, and high mortality. Further research is needed to examine and link observations obtained from positive results from the identification of pathogenic Leptospira bacteria in rat urine with human examination as a preventative measure for the spread of disease and control of mice (Far, 1995; Farrar, 1995).

Leptospires can cause systemic infections in mice for seven to nine days but are quickly repaired from tissue except in the kidney tubules, bacteria can survive and be released into the environment for several months (Holk et al., 2000; Athanazio et al., 2008). Leptospirosis occurs in various epidemiologies, but in low socioeconomic areas or areas with high rat abundance, the risk of Leptospira transmission is higher (Costa et al., 2014b). A survey of zoonotic pathogens conducted in populations of house mice and black rats in Yucatan, Mexico shows that reproduction rates of synanthropic rodents are high in low socioeconomic areas, which can increase public health risks (Panti-May et al., 2017).

\section{Conclusion}

The conclusion are this research shows the presence of pathogenic leptospira bacteria in mice living in the Banyuwangi area, this could be a risk of transmitting leptospirosis to humans or livestock related to the environment such as sewers, sewage, etc. In addition, it is important to emphasize that leptospirosis can be transmitted by mice to pets and this can be a further danger to animal and human health.

\section{References}

Adler, B dan de la Peña Moctezuma A, 2010. Leptospira and leptospirosis. Veterinary microbiology, 140(3-4), pp.287-96. 
Amin, L. Z. 2016. Leptospirosis. 43, 576-580.

Athanazio, D. A. et al. (2008) 'Rattus norvegicus as a model for persistent renal colonization by pathogenic Leptospira interrogans', Acta Tropica, 105(2), pp. 176-180. doi: 10.1016/j.actatropica.2007.10.012

Bal, A. E., Gravekamp, C., Hartskeerl, R. A., De Meza-Brewster, J., Korver, H., \& Terpstra, W. J. 1994. Detection of leptospires in urine by PCR for early diagnosis of leptospirosis. J. Clin. Microbiol. 32, 1894-1898 https://doi.org/10.1128/jcm.32.8.18941898.1994.

Costa, F. et al. (2015) 'Global Morbidity and Mortality of Leptospirosis: A Systematic Review', PLoS Neglected Tropical Diseases, 9(9), pp. 0-1. doi: 10.1371/journal.pntd.0003898.

Costa, F., Porter, F. H., Rodrigues, G., Farias, H., De Faria, M. T., Wunder, E. A., Osikowicz, L. M., Kosoy, M. Y., Reis, M. G., Ko, A. I., \& Childs, J. E. 2014a. Infections by Leptospira interrogans, seoul virus, and bartonella spp. among norway rats (rattus norvegicus) from the Urban slum environment in Brazil. Vector-Borne Zoonotic Dis. 14, 33-40 https://doi.org/10.1089/vbz.2013.1378.

Costa, F., Ribeiro, G. S., Felzemburgh, R. D. M., Santos, N., Reis, R. B., Santos, A. C., Fraga, D. B. M., Araujo, W. N., Santana, C., Childs, J. E., Reis, M. G., \& Ko, A. I. 2014b. Influence of Household Rat Infestation on Leptospira Transmission in the Urban Slum Environment. PLoS Negl. Trop. Dis. 8 https://doi.org/10.1371/journal.pntd.0003338.

Farr RW. Leptospirosis. Clin Infect Dis 1995; 21: 1ะ8. 8.

Farrar WE. Leptospira species (leptospirosis). In: Mandell GL, Bennett JE, Dolin R, editors. Principles and practice of infectious diseases. 4th ed. New York: Churchill Livingstone, 1995: $2137 \pm 41$.

Gratz, Norman. 2006. Vector- and Rodent-borne Disease in Europe and North America. Cambridge University Press. www.cambridge.org/9780521854474

Holk, K., Nielsen, S. V. and Ronne, T. (2000) 'Human leptospirosis in Denmark 1970-1996: An epidemiological and clinical study', Scandinavian Journal of Infectious Diseases, 32(5), pp. 533-538. doi: 10.1080/003655400458839.

Katulistiwa, N. A. and Lestari, K. S. (2015) 'Analisis kondisi rumah dan keberadaan tikus yang berpengaruh terhadap kejadian leptospirosis di Kabupaten Klaten', Jkl, 8(1), pp. $1-13$.

Khairiyah. 2016. Zoonosis dan Upaya Pencegahannya (Kasus Sumatera Utara). Zoonosis dan Upaya Pencegahannya (Kasus Sumatera Utara) 30, 117-124 https://doi.org/10.21082/jp3.v30n3.2011.p117-124. 
Meerburg, B. G., Singleton, G. R., \&amp; Kijlstra, A. 2009. Rodent-borne diseases and their risks for public health Rodent-borne diseases and their risks for public health.

Mulyono, Arief. Ristiyanto. Rahardianingtyas, Esti. Putro, DGB. Joharina, AS. 2015. Prevalensi dan Identifikasi Leptospira Patogenik Pada Tikus Komensal Di Kota Maumere, Flores. Vektora Volume 8 Nomor 1, Juni 2016: 31 - 40

Panti-May, J. A. et al. (2017) 'A survey of zoonotic pathogens carried by house mouse and black rat populations in Yucatan, Mexico', Epidemiology and Infection, 145(11), pp. 2287-2295. doi: 10.1017/S0950268817001352.

Sarkar U, Nascimento S F, Barbosa R, Martins R, Nuevo H, Kalafanos H, Grunstein I, Flannery G, Dias J, Riley L W, Reis M G and Ko A I 2002 Population-based casecontrol investigation of risk factors for leptospirosis during an urban epidemic; Am. J. Trop. Med. Hyg. 66 605-610

Shieh WJ, Edwards C, Levett PN, Zaki SR. 2006. Leptospirosis, p 511-518. In Guerrant RL, Walker DH, Weller PF (ed), Tropical Infectious Disease: Principles, Pathogens and Practice. Elsevier Churchill Livingstone, Philadelphia, PA.

Wagenaar, J., Zuerner, R. L., Alt, D., \& Bolin, C. A. 2000. Comparison of polymerase chain reaction assays with bacteriologic culture, immunofluorescence, and nucleic acid hybridization for detection of Leptospira borgpetersenii serovar hardjo in urine of cattle. Am. J. Vet. Res. 61, 316-320 https://doi.org/10.2460/ajvr.2000.61.316.

Widoyono. 2011. Penyakit Tropis Epidemiologi, Penularan, Pencegahan, dan Pemberantasannya. Jakarta: Penerbit Erlangga. 